\title{
Teachers' Motivational Strategies: The Awareness of Gender-Related Differences
}

\author{
Irma Soraya \\ UIN Sunan Ampel Surabaya
}

\begin{abstract}
Students' motivation is an essential part of EFL teaching and learning process at any level of education. Secondary school is a level of education with a milieu in which students, who are adolescents, need motivation for learning to be successful learners and have a better future. For that kind of objectives, the EFL teachers carry out motivational strategies to help the students to do so. The motivational strategies done by one teacher are different from another. This current study aims at exploring motivational strategies used by EFL secondary teachers with different gender, male and female. Qualitative research design, with observation and interview, was conducted to explore the practical differences. The participants involved in this study were two teachers with different gender, male teacher and female teacher, as well as their students. Through this study, it was found out that there were differences between the motivational strategies done by a male teacher and female teacher which related to their gender. Although they did the same kind of some motivational strategies, the way and the work of those strategies were not the same. The result of this study is expected to give a contribution towards not only the conceptual knowledge related to motivational strategies and gender but also the practice of EFL teaching and learning.
\end{abstract}

Keywords: communicative activities, language teaching \& learning process, teacher training session

\section{INTRODUCTION}

Indonesia becomes one country which has accomplished important step dealing with the development of students' English communicative skills. It could be seen from the exertions that have been dedicated to improve the teaching and learning of EFL (English as a Foreign Language) at schools in Asian countries (Nunan, 2003; Spolsky\& Sung, 2015). The main purpose of learning English is for communication. Therefore, the essence of communication cannot be separated from English language learning. Students need to be able to communicate with others using English. To help them with that goal, there is a need from teacher to foster students' communicative ability in English so that they successfully achieve the main goal of learning English.

Language learning process can be succeeded when there is an engagement between learners and the learning environment they are involved in. Through a good engagement, the learners can have interest in learning the target language which will lead them to be successful learners through successful language learning.Regarding to the students' interest in language learning, teachers should build students' motivation to promote successful learning. Motivation is one element that can be developed into strategies in relation to the practice of teaching and learning in the classroom.Teachers as the main person coping with students, need to be able to motivate the students in order to help them develop their English skills. In this case, teachers are expected to implement motivational strategies to make it true.

Motivational strategies, as a way of teachers to help students develop their English as what has been explained previously, have been applied in some places with different contexts. Dornyei (2001), as the initiator of strategies in building motivation in classroom, developed concepts and theories of motivational strategies in teaching practice called Motivational Teaching Practice (MTP). It then became popular as teachers' motivational strategies.

Motivational factors are needed by teachers in dealing with that condition. It is in line the study conducted by with Ryan and Deci (2000) which suggested that motivational factors can influence students' performance and also a study by You (2004) which investigated the positive effect of teaching motivational strategies on students' achievement. In addition, Gardner and Lambert (1959) stated that students' ultimate outcome in EFL classroom affected by individual's motivation. It can be seen from the students' attitudes and orientation of learning. Seeing the importance of language teachers' role in initiating students' motivation, therefore, proper teachers' motivational strategies must be considered to the effectiveness of language learning. 
There are some studies investigating motivational strategies used by teachers in EFL classrooms. One of them is a study conducted in Pakistan by Kakar and Pathan (2017) which showed that teachers often applied familiarization L2 related values to students as their strategies to promote learners' autonomy in learning. The second one is a study by Al qahtani (2016) which investigated that macro teaching strategies were frequently used by teachers in Saudi to successfully switch on the students' motivation in learning English. In Indonesia,Astuti's study (2016) showed that teachers of secondary high schools in Indonesia employed five strategies in promoting students' motivation.Astuti conducted a research on the motivational strategies used by senior high school teachers who are successful in motivating their students to learn English.

Every human being is not the same and the way they do something tend not to be exactly the same. It goes also for motivational strategies or motivational teaching practices in which there is possibility for them to carry out different ways in order to achieve doing certain strategies.Seeing from non-environmental factors, there is a possibility that the teacher's gender gives contribution towards the way of the motivational strategies were practiced in the field. Therefore, this research aims at exploring motivational strategies used by EFL secondary teachers with different gender, male and female as well as analyze the differences of the motivational strategies carried out by teachers with different gender across levels of secondary schools, including Junior High School and Senior High School.

\section{Motivational Strategies}

Techniques that promote the learner's goalrelated behaviours which are known as motivational strategies. In other word, Dörnyei states that motivational strategies deal with process of motivating a person intentionally to pursue plans and attain certain effect (Dörnyei, 2001). Motivational strategies include the instructional interventions applied by the teacher to generate and stimulate student motivation and self- regulating strategies used purposefully by individual students to manage the level of their own motivation (Guilloteaux\&Dörnyei, 2008).

To organize motivation, the classroom practitioners should apply the diverse techniques. Dörnyei made several systematic attempts in motivating learners which are organized in four motivational dimensions (Dörnyei\&Ushioda, 2011).

Creating basic motivational conditions. The early way to motivate learners requires the teachers to generate motivation effectively among learners. It can be attained by creating these following three conditions: (1) appropriate teacher behaviours, (2) a pleasant and supportive classroom atmosphere, and (3) a cohesive learner group with appropriate group norms (Dörnyei, 2001).

Generating initial motivation. In establishing motivation in classroom, teachers face the problem on how to find ways to encourage their students to accept the learning goals and to enjoy the classroom activities (Dörnyei, 2001). The dimension of motivational strategies is set to increase the learner's expectancy of success and develop positive attitude toward the language learning (Guilloteaux\&Dörnyei, 2008).

Maintaining and protecting motivation. To maintain and protect the learner's motivation, the teachers should make learning stimulating and enjoyable, present tasks in a motivating way, set specific learner goals, protect the learners' selfesteem and increase their self-confidence, allow learners to maintain a positive social image, promote cooperation among the learners, create learner autonomy, and promote self-motivating learner strategies (Dörnyei\&Ushioda, 2011).

Encouraging positive retrospective selfevaluation. This last phase of motivational strategies deals with the learners' reactions toward their past performance. This phase is going to show how the teachers are capable of leading learners in evaluating their achievement to become better in future (Dörnyei, 2001). The teachers can conduct this phase by promoting adaptive attributions, providing effective and encouraging feedback, increasing learner satisfaction, and offering grades in a motivational manner (Guilloteaux\&Dörnyei, 2008).

Based on Dörnyei's (2001) concept of motivational strategies, the initial stage to motivate students in EFL learning engagement is creating basic motivational conditions. This phase is conducted to stimulate students' motivation in learning EFL before any further attempts stepped. There are three important points this motivation phase: 1) Appropriate teacher behavior and a good relationship with the students, 2) A pleasant and supportive atmosphere in the classroom, and 3) A cohesive learner group with appropriate group norms.

There are some studies related to maintaining motivational strategies that have been done previously. A study conducted by Nichols(2014) showed that the teacher has willingness to be open and share his or her life with students is the essential element to motivational strategy which relates to teacher's personality. This indicated that the role of the teacher is very important for the students' motivation in learning. 
Another study conducted by Astuti (2016) showed that the most influential teachers' motivational strategy was EFL classroom teacher's behavior. The teacher's behavior which motivated students could be seen from the teacher's smile, facial expression, jokes, and clear instruction in delivering lesson. Meanwhile Koran's (2015)studyconducted in Iraq, recommended that teacher need to investigate the purpose of students in learning language so they can motivate students in such a way. When teachers know their pupils needs, they try to give the most to obtain a better effect on students learning. Viewing beyond, Alqahtani(2016), according to the result of his study, states that the top rank of motivational strategies was teacher behaviour.Supportive classroom is also important elements in motivational strategies according to Astuti(2016) and Alqahtani (2016). Different students' character, environment and teachers' competence make the effect on students' motivation varied. Teachers with different gender also have their own ways in motivating their students.

\section{Gender and Teaching}

A teaching-learning process involved teachers as the ones who directly contacted with the classroom as well as the students. The role of a teacher is essential that what goes in the classroom depends on the teacher. Teachers play an important role in creating, maintaining, and influencing a school's climate (Dessel, 2010a, Garnett et al., 2014; Poteat\&Vecho, 2015; Wernick et al., 2014). Meanwhile, it is important also to realize that teachers are human being and they have social and natural categorization which are also represented in their personalities and their ways to do things. Furthermore, teachers hold authoritative positions in classroom settings, a space where they help develop and guide the language and behavior of students. (Dessel, Kulick, Wernick, Sullivan; 2017). Therefore, the one who can motivate the students the most is the teachers.

Confounding influences of student traits, amongst others, socio-economic status, ethnicity, intelligence, and existing behavioral problems, could also be an explanation for the in-consistent results in the literature so far. Nonrandom placement with a male or female teacher with regard to these factors might also confound results. (Zeew, Beijstervedt, Glasner, Bartels, Geus, Boomsma; 2014). The teachers' different gender can also influence the how they act and give impacts towards the students in terms of what they do and ho they treat the students.

\section{METHOD}

As this study aims at exploring motivational strategies used by EFL secondary teachers, qualitative research design was used as the basis of the implementation.Two secondary schools in Surabaya were chosen as the setting in which this study was carried out in which one English teacher from each school was picked as the subjects of this study. Two of the teachers are male, and the others are female. The two secondary schools are different in terms of level of secondary school in which one of them is Junior High School and the other one is Senior High School. Both schools are in Surabaya. The subjects chosen, the teachers, were selected through certain procedure including the giving of consent form and also the pilot study done previously which directs them to be the ones who are good at motivating students.

The data were collected through observation and interview respectively. Observation was carried out in order to see what motivational strategies done by those subject teachers. In other words, observation was used to reveal the teachers' actions of motivational strategies that they practiced in their classroom. Therefore, observation checklist was used as one of the instruments of this study. It was developed based on Dornyei's (2001) theory of motivational strategies that have been operationalized to be observable.

Through the observation checklist the analysis was done to see the motivational strategies which contain differences in a way that male and female teachers did, but all of them did the strategies. Interview then was conducted to confirm the results of the observation checlist as well as for the benefit of triangulation.

\section{FINDINGS AND DISCUSSION}

After doing the data analysis, this study found that there are several motivaltional teaching strategies or motivational teaching practices in which teachers with different gender have different way on how to carry them out in their own classroom. The motivational strategies include how to establish enjoyment in the classroom and in the process of teaching, how to show their care towards the students, how to praise the students, how to provide various modes of resources and media, and also how to show the importance of English today.

The first motivational strategy that showed difference in terms of how it is carried out by teachers with different gender, is establishing enjoyment in the classroom and in the process of teaching. In this case, the action is about how the teacher made jokes which revealed that the male teachers tended to throw unique jokes that the students tended to laugh because of them. 
Meanwhile, the female teachers tended to throw jokes which are flat, meaning that they had great effort to give it but the students tended not to laugh for the jokes. Some jokes delivered by the female teachers were also way too common that they had been recognized by the students

In showing his or her care to the students, the male and female teachers has difference in how they ask their students' condition, specifically how they deal with the student with bad condition when they are in the classroom situation. From this study, it is found out that the male teachers asked about the student condition in formal way in which they tended to ask for general questions. Furthermore, the male teachers did not come closer to the student who looked unwell or was in bad condition, and they did not touch the student. There was a distance that the male teachers provide between them and their students, especially the female students. In contrast, the female teachers tended to ask the student's condition in detail and they came closer to the student who was in bad condition. They even touch the student and showed their "motherness" toward the student.

The difference between male and female teachers in motivating their students also happened when they praised the students, especially for the verbal praises. The male teacher tended to give verbal praises adequately as shown in this study. Both male teachers had flat intonation and rarely used gestures or body language when they were praising his students who did good. Meanwhile, the female teachers used various intonation with body gestures when they were praising her students verbally. For example, in meeting 2 of the classroom observation, FM2 she said "good job" to the student while showing two thumbs up.

The next difference revealed through this study is about the teachers' way of providingmodes of resources and media in their teaching. This study found out that the male teacher tended to use learning resources which were easy to get such as the ones in the textbooks or youtube. In addition, the media they used were also simple and easy to use. However, the they always used what they had optimally and made sure that the students get the main material. In contrast, the female teachers tended to be more creative in terms of learning resources and media since they used various ones. Ths study found that the female teachers, in this case, were more creative in managing nad utilizing media in the classroom. They had great effort on how to provide various modes of learning resources and media

Showing the importance of English today dealing with bringing up-to-date issues to the class becomes the next motivational strategy that differed in male teacher's class and female teacher's one. In this study, it is found out that the up-to-date issues brought by the male teachers in the classroom tended to be about political and social issues. Meanwhile, the female teachers tended to bring recent entertaiment or environmental issues in the English classroom and mostly they related the issues into the topic or material that they and her students were discussing. This also happened for the male teachers. The difference was on the topic of the issue that they related.

Lastly, this study also found differences between female and male teachers in terms of the way of showing the importance of English today, notably in giving assignments or tasks which support students to learn English. The male teachers were found to have tendency of giving less tasks. Moreover, they tended to rely on on-the-spot activities and also interactional tasks since, for them, such way was considered more effective for students to learn English. On the contrary, the female teacherstended to give more tasks compared to the male teachers. The tasks that they gave also varied but mostly they were individual ones. One of them, FM 1 thought that through the tasks given, the students learn a lot and at the same time the result shows how far their understanding is.

Although the two teachers, the male and the female teacher, taught the same level of students and alsodid the same kind of some motivational strategies but the way and the work of those strategies were not the same. This difference means that there are things beyond that give impacts toward it. Since two of the teachers are male and the other ones are female, it is possible to say that their gender relates to their motivational strategies that they implement in their classroom in which each gender has its own way to carry out the strategies in their own classroom. This supports Sansone's (2017) statement that teacher's gender possibly affects the teacher's behavior.

Through the findings that have been mentioned previously, it can be seen that the female teachers tend to be softer and unconsciously show the element of being a mother at some strategies. Meanwhile, male teachers tend to be more relaxed. The language classroom consists of unique socioeducational environment (Nikitina \&Furouka, 2007). It means that this kind of detailed finding exists in the context since the ones involved are social beings and there is uniqueness within the context.

The findings of this study also indicate that the difference of male and female gender roles that the teachers have goes across two differentlevels of 
secondary school, Junior High School and Senior High School. The strong similarities found from the female teachers both in Junior High School and Senior High School emphasize that their gender role as female is a strong factor dealing with the way of them implement the motivational strategies in their classroom. Such pattern also prevails for the male teachers from two different levels of secondary school.

Different gender having different ways of giving motivational strategies poses different impacts towards the students. Gender differences in using language are available in the EFL classrooms (Ali, 2016). It starts from the teacher, then it affects the students. It possible also that further investigation is done, the gender-related differences can come up to the students as the one who are taugh by the teachers with different gender. The uniqueness will touch that context, which may not be realized by the teachers nor the students.

\section{CONCLUSION}

To sum up the things found through this study, there were differences existing in the practice of motivational strategies done by English male teachers and English female teachers in their English classroom, which related to their gender as male and female. The differences copes with the way they carry out the strategies and also the elements that they involved. The results of this study also emphasize that it is important to raise awareness of gender-related differences in motivational strategies or motivational teaching practices.

This study also suggest for further investigation dealing with the same variables involving motivational strategies and also gender, which relates to the subjects of research. Further investigation can also be done to see which one is more effective and do this kind of differences also occurs in different kind of contexts including level of school or the geographical matters.

\section{REFERENCES}

[1] Ali, Hawkar O. (2016). Gender Differences in Using Language in the EFL Classes: From Teachers' Views. International Journal of Humanities and Cultural Studies, 2 (4).

[2] Alqahtani, S. (2016). Motivational Strategies and EFL Teachers' Perceptions: A Saudi Survey. Theory and Practice in Language Studies, 6(4), 663

[3] Astuti, S. P. (2016). Exploring motivational strategies of successful teachers. TEFLIN Journal, 27(1), 1-22.

[4] Nikitina, L. \& Furuoka, F.2007. Language Classroom: A "Girls' Domain"? Female And Male Students' Perspectives On Language Learning. MICOLLAC

[5] Dessel, A. B., Kulick, A., Wernick, L. J., Sullivan, D. (2017). The importance of teacher support: Differential impacts by gender and sexuality. Journal of Adolescence, 56, 136-144
[6] De Zeeuw, E. L., van Beijsterveldt, C. E. M., Glasner, T. J., Bartles, M., de Geus, E. J C., Boomsma, D. I. (2014). Do children perform and behave better at school when taught by same-gender teachers?. Learning and Individual Differences, 36, 152-156.

[7] Dornyei, Z. (2001). Motivational strategies in language classroom. Cambridge: Cambridge University Press.

[8] Dörnyei, Z., \& Ushioda, E. (2011). Teaching and researching motivation. Harlow: Pearson Education Limited.

[9] Gardner, R. C., \& Lambert, W. E. (1959). Motivational variables in second language acquisition. Canadian Journal of Psychology, 13(4), 266-272.

[10] Garnett, B. R., Masyn, K. E., Austin, S. B., Miller, M., Williams, D. R., \& Viswanath, K. (2014). The intersectionality of discrimination attributes and bullying among youth: An applied latent class analysis. Journal of Youth and Adolescence, 43, $1225 \mathrm{e} 1239$.

[11] Guilloteaux, M.-J., \& Dornyei, Z. (2008). Motivating language learners: A classroom-oriented investigation of the effects of motivational strategies on student motivation. TESOL Journal, 42(1), 55-77.

[12] Kakar, S. K. \& Pathan, Z. H. (2017). Exploring the Motivational Strategies Practiced by Pakistani EFL Teachers to Motivate Students in Learning English Language. International Journal of English Linguistics, 7(2), 117-123

[13] Koran, S. (2015). Analyzing EFL Teachers' Initial Job Motivation and Factors Effecting Their Motivation in Fezalar Educational Institutions in Iraq. Advances in Language and Literary Studies, 6(1), 72-80

[14] Ryan, R. M. \& Deci, E. L. (2000). Intrinsic and Extrinsic Motivations: Classic Definitions andNew Directions. Contemporary Educational Psychology, 25, 54-67.

[15] Sansone, D. (2017). Why Does Teacher Gender Matter?. Seconomics of Education Review.

[16] Spolsky, B., \& Sung, K. (2015). Secondary school English education in Asia: From policy to practice. New York: Routledge.

[17] Nichols, R. (2014). Motivating English language learners: An Indonesian case study (master's thesis). University of Texas at Arlington, USA.

[18] Nunan, D. (2003). The impact of English as a global language on educational policies and practices in the Asia-Pacific region. TESOL Quarterly, 37(4), 589613.

[19] Poteat, V. P., \& Vecho, O. (2015). Who intervenes against homophobic behavior? Attributes that distinguish active bystanders. Journal of School Psychology, 54, 17-28.

[20] Wernick, L. J., Kulick, A., \& Inglehart, M. H. (2014). Influences of peers, teachers, and climate on students' willingness to intervene when witnessing antitransgender harassment. Journal of Adolescence, 37, $927 \mathrm{e} 935$. 